\title{
Increased irisin abundance in muscle and blood circulation after treadmill exercise in mice
}

Julia Brenmoehl ${ }^{1}$, Elke Albrecht ${ }^{2}$, Katrin Komolka ${ }^{2}$, Lisa Schering ${ }^{2}$, Martina Langhammer ${ }^{3}$, Andreas Hoeflich ${ }^{1}$, and Steffen Maak ${ }^{2}$

${ }^{1}$ Institute of Genome Biology, ${ }^{2}$ Institute for Muscle Biology and Growth, ${ }^{3}$ Institute for Genetics and Biometry, Leibniz Institute for Farm Animal Biology (FBN) Dummerstorf, Germany

\section{INTRODUCTION}

Irisin, the exercise induced, secreted cleavage product of fibronectin type III domain-containing protein 5 (Fndc5), is a potential mediator of positive metabolic effects of exercise. It was demonstrated that recombinant Fndc5 induced a thermogenic program in white adipose tissue thus indirectly linking exercise with browning of adipose tissue (Bostroem et al., 2012). Cleavage and modification of Fndc5 was proposed as prerequisite for this action. The study investigated the effect of exercise on Fndc5/irisin and peroxisome proliferatoractivated receptor gamma co-activator 1-alpha (PGC1- $\alpha$ ) in mice.

\section{MATERIAL AND METHODS}

Animals and samples:

- 70 days old, male DUhTP mice (Dummerstorf high treadmill performance, selected over 117 generations)

- 3 groups, one bout of treadmill exercise at 70 days of age, voluntary wheel running for 3 weeks $\left(49^{\text {th }}\right.$ to $70^{\text {th }}$ day of age) or sedentary control, $n=11$ to 12 in each group

- Blood and leg muscles (femoral and crus)

mRNA expression:

- RNA extraction with Qiazol Lysis Reagent (Qiagen)

- cDNA synthesized with iScript cDNA Synthesis Kit (BioRad)

iQ-SYBR green supermix (BioRad) and gene-specific oligonucleotides (Table 1, final concentration $0.2 \mu \mathrm{M}$ )

Protein analyses:

- Western Blot of $20 \mu \mathrm{g}$ muscle protein or $30 \mu \mathrm{g}$ serum protein

- Detection with antibodies against full-length Fndc5 at $\sim 25 \mathrm{kDa}$ (AP8746b, BioCat) or irisin at $\sim 12 \mathrm{kDa}$ (A00170-01-100, Biotrend), PGC1- $\alpha$ (sc-13067, Santa Cruz Biotechnology), and HRP conjugated goat anti rabbit IgG secondary antibody (New England Biolabs)

Quantification with enhanced chemiluminescence (TMA-100, Lumigen technology, Bioquote Limited, York, UK), Kodak Image Station 4000 MM (Raytest) and Lablmage 1D software (Kapelan Bio-Imaging) Immunohistochemistry:

- Cryosections of femoris muscle, antibodies like for WB

- MFP488 labeled secondary antibody, visualized with a Nikon Microphot SA microscope and a CC-12 high resolution color camera (OSIS)

Statistical analysis:

- SAS 9.2, ANOVA using the MIXED model with fixed factor group and random animal

- CORR procedure for correlations between gene expression and running distance

Table 1. Sequences of primer sets used for amplification of specific cDNA

\begin{tabular}{|c|c|c|c|c|c|}
\hline Locus & Primer & bp & Sequence $5^{\prime}-3^{\prime}$ & Acc. No. & Position \\
\hline $\begin{array}{l}\text { B2m } \\
\text { (reference) }\end{array}$ & $\begin{array}{l}\text { forward } \\
\text { reverse }\end{array}$ & 175 & $\begin{array}{l}\text { СCTGGTCTTTCTGGTGCTTG } \\
\text { TTTCCCGTTCTTCAGCATTT }\end{array}$ & NM_009735 & $\begin{array}{r}69-89 \\
224-243\end{array}$ \\
\hline $\begin{array}{l}\text { Hprt1 } \\
\text { (reference) }\end{array}$ & $\begin{array}{l}\text { forward } \\
\text { reverse }\end{array}$ & 90 & $\begin{array}{l}\text { TCCTCCTCAGACCGCTTTT } \\
\text { CCTGGTTCATCATCGCTAATC }\end{array}$ & NM_013556 & $\begin{array}{r}104-122 \\
173-193\end{array}$ \\
\hline Fndc5 & $\begin{array}{l}\text { forward } \\
\text { reverse }\end{array}$ & 162 & $\begin{array}{l}\text { CAACGAGCCCAATAACAACA } \\
\text { AGAAGGTCCTCTCGCATTCTC }\end{array}$ & NM_027402.3 & $\begin{array}{l}553-574 \\
694-714\end{array}$ \\
\hline $\begin{array}{l}\text { PGC1- } \alpha \\
\text { transcript 1a }\end{array}$ & $\begin{array}{l}\text { forward } \\
\text { reverse }\end{array}$ & 156 & $\begin{array}{l}\text { GGACATGTGCAGCCAAGACTCT } \\
\text { CACTTCAATCCACCCAGAAAGCT }\end{array}$ & NM_008904.2 & $\begin{array}{r}148-169 \\
281-303\end{array}$ \\
\hline $\begin{array}{l}\text { PGC1- } \alpha \\
\text { transcript 3a }\end{array}$ & $\begin{array}{l}\text { forward } \\
\text { reverse }\end{array}$ & 103 & $\begin{array}{l}\text { AAGTGAGTAACCGGAGGCATTC } \\
\text { TTCAGGAAGATCTGGGCAAAG A }\end{array}$ & JX866947 & $\begin{array}{r}94-115 \\
175-196\end{array}$ \\
\hline $\begin{array}{l}\text { PGC1- } \alpha \\
\text { transcript } 4^{\mathrm{a}}\end{array}$ & $\begin{array}{l}\text { forward } \\
\text { reverse }\end{array}$ & 172 & $\begin{array}{l}\text { TCACACCAAACCCACAGAAA } \\
\text { CTGGAAGATATGGCACAT }\end{array}$ & JX866948 & $\begin{array}{l}687-706 \\
841-858\end{array}$ \\
\hline
\end{tabular}

${ }^{a}$ Ruas et al. 2012; Cell. 151: 1319-1331

We are grateful to L. Chau, S. Hinrichs, E. Schwitulla, S. Foß, S. Geist, B. Lucht, S. Alm, and K. Ullerich for expert technical assistance and animal care.

This work was supported in part by grants of the Leibniz Association (grant no. SAW-2013-FBN-3) and the Deutsche Forschungsgemeinschaft (grant no. DFG HO 2003/6-1).
Running performance:

\section{RESULTS}

$>$ Mice of the RW group, with free access to the running wheel, ran $4.7 \pm 2.6 \mathrm{~km}$ per day during 3 weeks of voluntary endurance exercise.

$>$ Mice subjected to a single submaximal test on a treadmill (TM group) ran $5.1 \pm 1.8 \mathrm{~km}$. Irisin abundance:

$>\operatorname{Irisin}(\sim 12 \mathrm{kDa})$ is abundant in murine muscle and circulates in serum.

$>$ Irisin abundance in serum and femoral muscle increased by acute exercise (Fig. $1 \mathrm{~A}, \mathrm{~B}$ ).
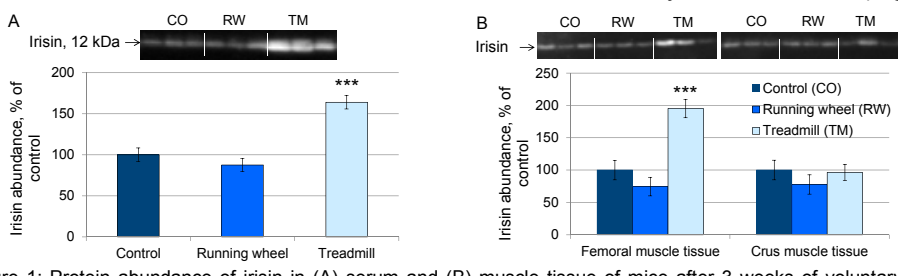

Figure 1: Protein abundance of irisin in (A) serum and (B) muscle tissue of mice after 3 weeks of voluntary exercise in a running wheel or one bout of treadmill exercise relative to a sedentary control. Representative parts of respective western blots are shown above the graphs. ${ }^{* \star}$ indicate significant difference to control $(P<0.001)$.

Fndc5 mRNA and protein abundance:

$>$ Fndc5 mRNA and protein abundance did not respond to exercise (Fig. $2 \mathrm{~A}, \mathrm{~B}$ ).

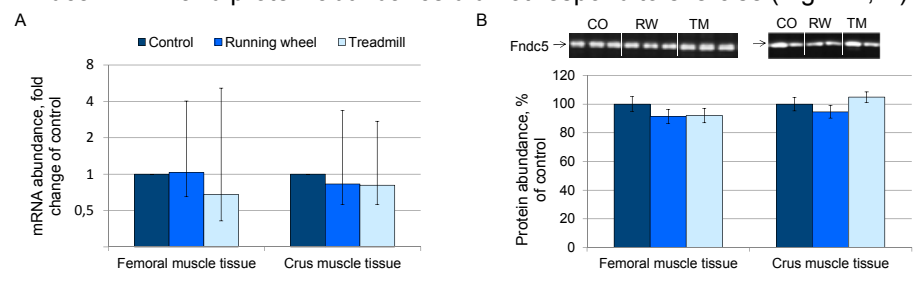

Figure 2: Fndc5 mRNA (A) and protein (B) abundance in muscle tissue of mice. (A) mRNA abundance was normalized to $\mathrm{B} 2 \mathrm{~m}$ and Hprt1. Bars represent means of fold changes compared to control group with $95 \%$ confidence intervals marked as vertical lines. (B) Protein abundance in \% of control. Representative parts of western blots are shown above.

Localization of Fndc5 and Irisin in muscle tissue:

$>$ Fndc5 was localized at the cell membrane and Irisin in the intercellular space between muscle fibers (Fig. 3 A, B).

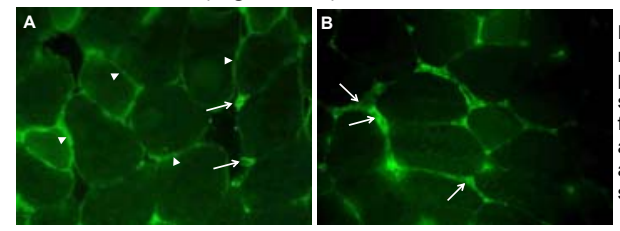

Figure 3. Cryosections of rectus femoris of a TM group mouse immunostained with anti-Fndc5 (A) or irisin (B) primary antibodies and MFP488 goat anti-rabbit IgG secondary antibody. Fndc5 was detected at the muscle fiber membrane (A, arrowheads) and in the cytoplasm, as well as in additional cells in the connective tissue (A, arrows). Irisin was mainly located in the intercellular space (B, arrows).

PGC1- $\alpha$ mRNA and protein abundance:

> Abundance of transcript 4 was 9- and 6-fold higher in TM compared to CO mice in femoral and crus muscles, respectively, and transcript 3 was 33- and 10-fold higher (Fig. 4 A, B).

$>$ PGC1- $\alpha 4$ mRNA abundance correlated with the running distance in TM group (Fig. 4C).

$>$ The protein abundance was not affected by exercise.

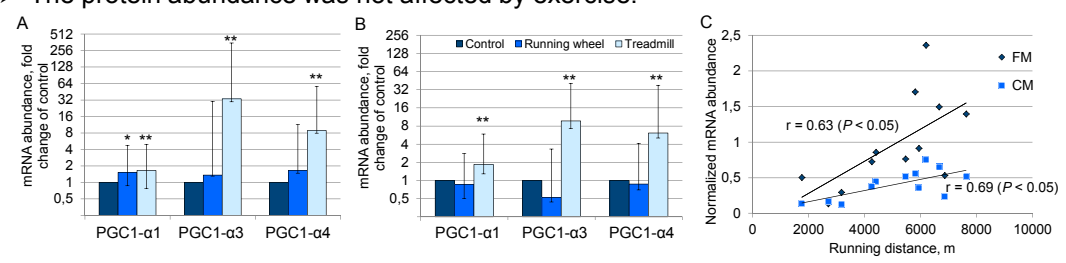

Figure 4: Expression of PGC1- $\alpha$ transcripts 1, 3, and 4 mRNA in femoral (A) and crus (B) muscle tissue of mice, normalized to $\mathrm{B} 2 \mathrm{~m}$ and Hprt1. Bars represent means of fold changes compared to control with $95 \%$ confidence intervals. * indicate Hprt1 (2- $\triangle \mathrm{CP})$, in femoral (FM) and crus (CM) muscles and running distance during one bout of treadmill exercise.

\section{CONCLUSION}

Our results indicate that irisin exists in skeletal muscle and serum of mice and increases immediately in response to acute but not to repeated voluntary exercise. Since this increase was not paralleled by an induction of PGC1- $\alpha$ protein and Fndc5 mRNA and protein it is likely that the acute irisin response is mediated by additional, unknown factors. The elevated mRNA abundance of different PGC1- $\alpha$ transcripts after acute exercise however, may indicate that PGC1- $\alpha$ induces recovery of muscular Fndc5 and irisin. 